\title{
Study Overall Status Date
}

National Cancer Institute

\section{Source}

National Cancer Institute. Study Overall Status Date. NCI Thesaurus. Code C94098.

The date (and time) on which the overall status of the study is assigned. 